\title{
Belajar Fotosintesis dengan Edugame Berbasis Android
}

\author{
Fitria Widya Astari, Endah Sudarmilah \\ Program Studi Informatika \\ Universitas Muhammadiyah Surakarta \\ Surakarta, Indonesia \\ fitriaastari98@gmail.com, endah.sudarmilah@ums.ac.id
}

\begin{abstract}
Abstraksi-Fotosintesis merupakan proses yang selalu dilakukan oleh tumbuhan untuk melangsungkan kehidupan. Proses fotosintesis berupa pembuatan makanan pada tumbuhan dengan menggunakan komponen berupa air, karbon dioksida dan cahaya matahari. Hasil dari proses tersebut berupa oksigen yang digunakan untuk bernafas oleh manusia dan glukosa untuk pertumbuhan tumbuhan atau disimpan dalam bentuk cadangan makanan. Saat ini penyampaian materi pada siswa hanya menggunakan buku dan belum divisualisasikan dengan baik sehingga susah dalam memahami. Materi fotosintesis merupakan salah satu materi pelajaran pada siswa kelas 5 sekolah dasar. Oleh karena itu, penulis merancang dan menciptakan sebuah game edukasi dengan tema fotosintesis yang bertujuan untuk memudahkan siswa dalam memahami materi fotosintesis. Game edukasi fotosintesis ini juga diharapkan dapat membantu siswa belajar dengan menyenangkan. Game ini merupakan game 2D yang dibuat dengan Construct 2 . Metode yang digunakan pada game edukasi ini adalah SDLC (System Development Life Cycle) dengan model waterfall. Berdasarkan pengujian dengan menggunakan System Usability Scale (SUS) mendapatkan hasil sebesar 71,83 menunjukkan bahwa aplikasi game edukasi fotosintesis memiliki kualitas yang baik dan dapat diterima pengguna.
\end{abstract}

Katakunci-android; construct 2; fotosintesis; game edukasi

\section{PENDAHULUAN}

Tumbuhan merupakan salah satu komponen yang berguna bagi kehidupan makhluk di bumi. Proses yang sangat mempengaruhi perkembangan suatu tumbuhan yaitu fotosintesis. Fotosintesis adalah suatu proses pembuatan makanan pada tumbuhan dengan bantuan energi cahaya [1]. Komponen yang berperan dalam proses fotosintesis berupa air, karbon dioksida dan cahaya matahari dengan hasil berupa glukosa/karbohidrat dan oksigen. Permasalahan muncul ketika siawa mulai bosan dengan cara penyampaian materi oleh guru. Kurangnya daya minat belajar pada siswa dalam pembelajaran biologi karena kurangnya cara penyampaian pesan atau informasi [2].

Seiring dengan perkembangan teknologi saat ini, Pembelajaran tidak hanya dilakukan dengan penjelasan semata melainkan dapat dilakukan dengan menggunakan media interaktif seperti game. Media pembelajaran digunakan untuk membantu memvisualkan bahan ajar yang bersifat abstrak dan juga membuat proses pembelajaran lebih menarik [3]. Siswa sekolah dasar pada umumnya menyukai sesuatu yang menarik sehingga menimbulkan kemauan untuk mempelajarinya.

Waktu yang dihabiskan anak-anak dan remaja bermain video game terus meningkat [4]. Maka, media pembelajaran menggunakan game atau yang disebut game edukasi sangat tepat untuk siswa. Game edukasi adalah salah satu jenis media yang digunakan dalam memberikan pengajaran yang berupa permainan dengan tujuan untuk merangsang daya pikir dan meningkatkan konsentrasi dan memecahkan masalah [5].

Kenaikan minat siswa dalam belajar melalui metode game dalam studi sosial diperoleh hasil siswa merasa senang saat mempelajari ilmu sosial, merasakan antusias, dan menjadi lebih aktif di kelas [6]. Metode game dapat membuat siswa menjadi semangat dalam belajar, karena tanpa adanya paksaan game sudah disukai oleh siswa.

Daya tangkap pembelajaran yang baik lebih ditekankan kepada pendidikan visual yang terlihat menarik dengan tambahan gambar dan efek suara [7]. Metode pembelajaran menggunakan game menunjukkan bahwa tidak berarti hanya memperoleh informasi, tapi berpotensi mengubah perilaku dan kepribadian juga [8]. Sikap siswa tampak lebih baik dan hasil tes tampak lebih baik [9].

Game edukasi sangat menarik untuk dikembangkan [10]. Oleh karena itu, penulis akan membuat game menggunakan Construct 2 pada platform android. Construct 2 merupakan sebuah aplikasi yang digunakan untuk membuat game 2D berbasis HTML5[11]. Browser dapat melakukan review pada game karena berbasis HTML5.Construct 2 tidak menggunakan bahasa pemrograman, tetapi menggunakan evensheet yang terdiri dari event yang disusun berdasarkan logika. Construct 2 merupakan game engine yang cocok untuk membuat game 2D dengan proses scripting yang lebih sederhana hanya dengan drag and drop dengan menggunakan logika sederhana pada Event Sheet [12]. 
Berdasarkan manfaat dari media pembelajaran menggunakan game, game edukasi 'Power Fotosintesis' dapat menambah minat belajar siswa dengan menjadikan proses belajar yang menyenangkan. Fokus game 'Power Fotosintesis' dengan genre adventure, pemain dapat membantu tumbuhan untuk melakukan fotosintesis. Dijelaskan pula komponen yang membantu proses terjadinya fotosintesis. Selain dari sisi pembelajaran materi, siswa diharapkan memiliki kesadaran terhadap manfaat menjaga lingkungan terutama tumbuhan. Melihat manfaat dari tumbuhan selain menjaga bumi juga memberikan kontribusi berupa oksigen yang merupakan hasil dari proses fotosintesis untuk makhluk lainnya.

\section{METODE}

Metode yang digunakan untuk merancang dan membuat game edukasi ini adalah SDLC (System Development Life Cycle) dengan model waterfall. Tahapan utama dari model waterfall langsung mencerminkan aktivitas pengembangan dasar [13].

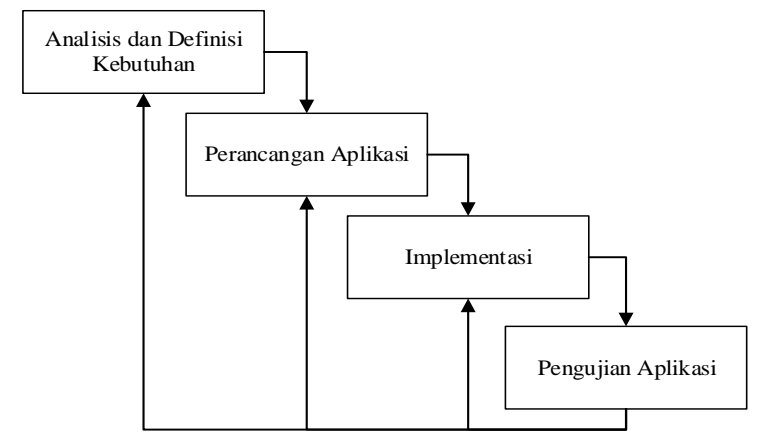

Gambar 1. Model Waterfall

Keterangan dari beberapa tahapan dalam metode yang digunakan:

\section{A. Analisis dan Definisi Kebutuhan}

Melakukan analisis kebutuhan untuk membuat game edukasi 'Power Fotosintesis' dimulai dari ide dasar kemudian penulis melakukan analisis mulai dari menentukan tema, target audience, teknologi hingga media/platform yang akan digunakan. Analisis terhadap kebutuhan perangkat keras (hardware) maupun perangkat lunak (software) yang digunakan. Peralatan yang digunakan dalam pembuatan game edukasi fotosintesis sebagai berikut:

Tabel 1. Kebutuhan Hardware dan Software

\begin{tabular}{|ll|l|}
\hline \multicolumn{1}{|c|}{ Hardware } & \multicolumn{1}{c|}{ Software } \\
\hline a. Laptop Acer Aspire V5- & a. Construct 2 r265 \\
& $\begin{array}{l}\text { 471 Intel @ Core TM i3 } \\
\text { 2365, RAM 2GB }\end{array}$ & b. Adobe Photoshop CS6 \\
b. Adobe Illustrator CS5 \\
$\begin{array}{l}\text { Handphone dengan sistem } \\
\text { operasi Android }\end{array}$ & & \\
\hline
\end{tabular}

\section{B. Perancangan Aplikasi}

Penulis merancang desain yang akan diterapkan dalam game edukasi mulai dari pembuatan karakter dengan storyline dan storyboard serta asset termasuk suara/musik yang sesuai dengan tema game.

a. Menyusun storyline

Tabel 2 Storyline Power Fotosintesis

\begin{tabular}{|l|l|}
\hline Konsep & Membantu tumbuhan melakukan fotosintesis \\
\hline Target audience & Siswa sekolah dasar kelas 5 \\
\hline Genre & Adventure \\
\hline Platform & Android \\
\hline Storyline & $\begin{array}{l}\text { Game ini mempunyai tokoh berupa tumbuhan } \\
\text { kaktus yang memiliki nama Saguaro. Merupakan } \\
\text { tumbuhan gurun yang yang dapat bertahan hidup } \\
\text { dalam kondisi ekstrim. Dimana tumbuhan ini } \\
\text { sangat memerlukan fotosintesis untuk } \\
\text { pertumbuhannya. Game ini merupakan game 2D. } \\
\text { Sebelum permainan dimulai, tumbuhan } \\
\text { memberikan misi kepada player bahwa tumbuhan } \\
\text { memerlukan bantuan untuk mendapatkan energi } \\
\text { dengan mengambil CO dan } \mathrm{H}_{2} \mathrm{O} \text { dan cahaya } \\
\text { matahari. Pada intro permainan disebutkan bahwa } \\
\text { hasil dari fotosintesis ini berupa glukosa }\left(\mathrm{C}_{6} \mathrm{H}_{12} \mathrm{O}_{6}\right) \\
\text { dan oksigen }\left(\mathrm{O}_{2}\right) . \text { Tumbuhan melakukan perjalanan } \\
\text { dimana dalam mendapatkan poin harus mengambil } \\
\text { CO }{ }_{2}, \mathrm{H}_{2} \mathrm{O} \text { dan matahari. Sebaliknya jika tumbuhan } \\
\text { mengenai zat kimia dan ulat nyawa akan } \\
\text { berkurang. }\end{array}$ \\
\hline
\end{tabular}

\section{b. Menyusun storyboard}

Penulis merangkai storyboard yang merupakan gambaran dari urutan atau alur game edukasi 'Power Fotosintesis' pada Tabel 3.

Tabel 3. Storyboard Power Fotosintesis

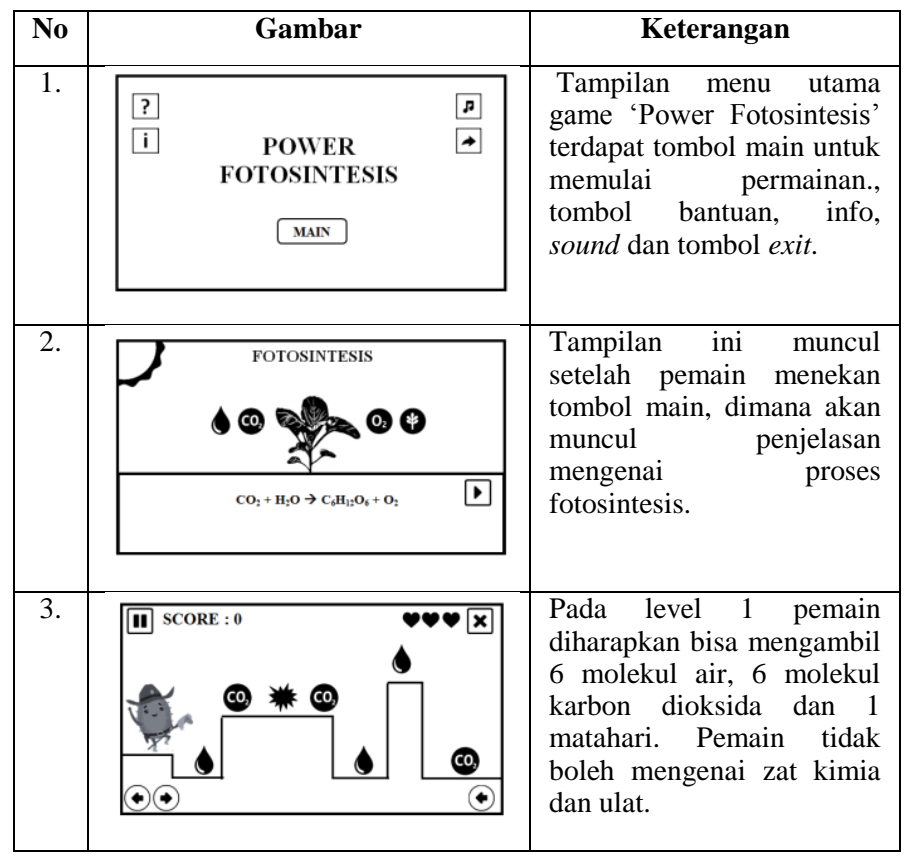




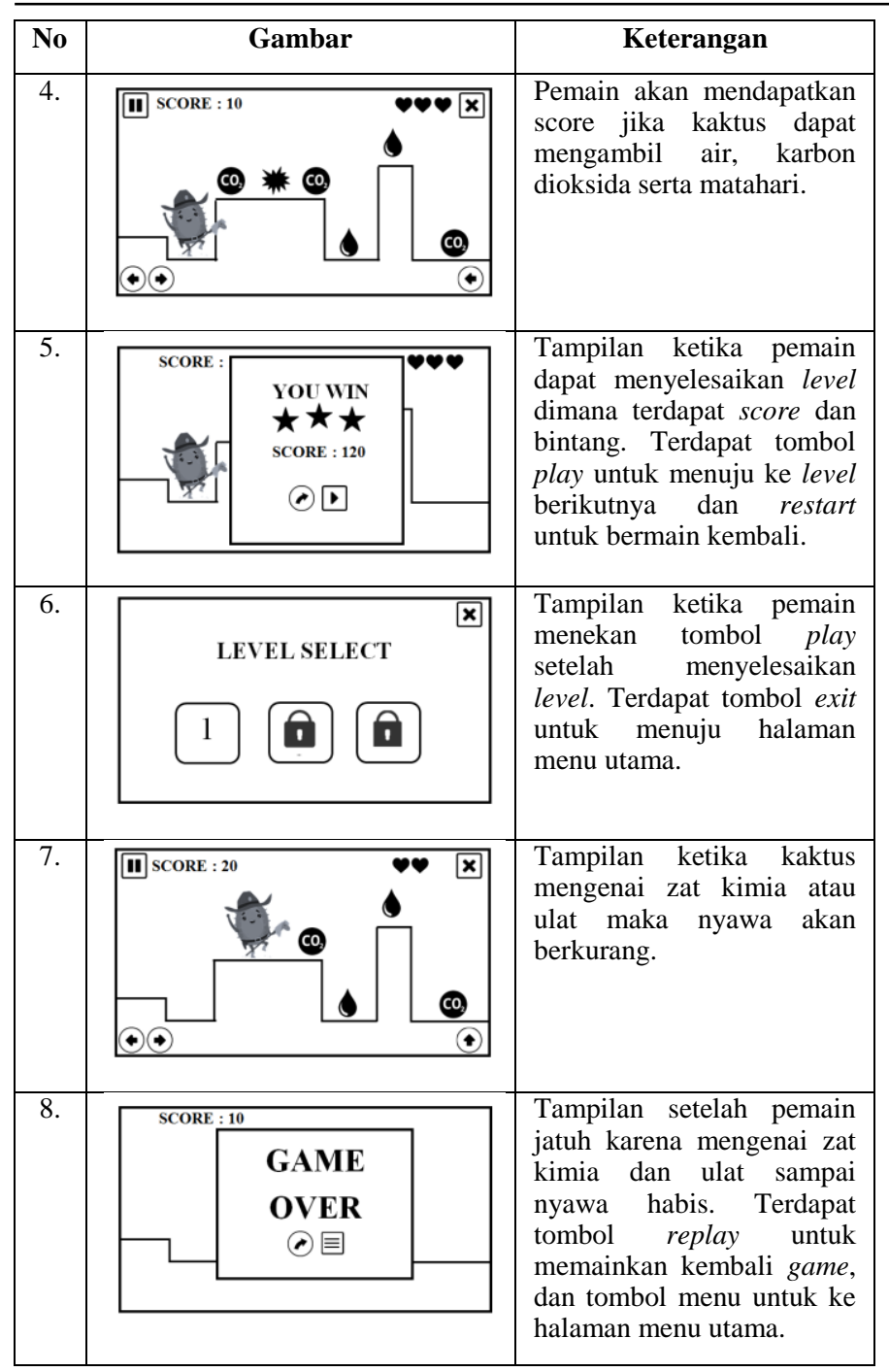

c. Menyiapkan asset dan sound

Penulis menyiapkan asset dan sound yang akan digunakan dalam game edukasi bagi pemain agar mendapatkan pengalaman bermain yang menyenangkan. Pembuatan asset game yang sesuai dengan storyboard yang sudah dirancang menggunakan aplikasi Adobe Photoshop CS6 dan Adobe Ilustrator CS5. Sound yang digunakan pada game ini seperti saat melakukan petualangan di alam dengan sound effect yang muncul ketika kaktus dapat mengenai air, karbondioksida dan matahari.

\section{Implementasi}

Penulis membuat aplikasi dengan melihat kebutuhankebutuhan dan desain yang sudah diubah kedalam bahasa pemrograman untuk membuat game edukasi menggunakan Construct 2 r265 sehingga menjadi game yang nyata.

\section{Pengujian Aplikasi}

Tahap pengujian terhadap game untuk mengetahui apakah secara keseluruhan game sudah berfungsi dengan baik, serta melakukan perbaikan jika diperlukan. Karena game ini berbasis android maka testing dilakukan di smartphone dengan sistem operasi android minimal versi 5.0 lollipop. Metode pengujian yang diterapkan pada game 'Power Fotosintesis' adalah pengujian balck box testing. Penguji game tidak harus mengerti mengenai source code, karena penguji dapat mengetahui kesalahan dari input yang telah diberikan. Apabila input yang diberikan menghasilkan output yang sesuai, maka aplikasi dapat berfungsi baik. Metode System Usability Scale (SUS) juga dilakukan dengan cara mengujikan game kepada siswa kelas 5 SD Negeri Pabelan 2 dengan jumlah responden sebanyak 30 siswa.

\section{HASIL DAN PEMBAHASAN}

Hasil dari penelitian ini berupa game edukasi tentang materi fotosntesis yang dapat memudahkan siswa dalam memahami materi dan menyenangkan dalam proses belajar. Game edukasi fotosintesis ini menggunakan platform android dimana dalam pembuatannya menggunakan game engine berupa Construct 2. Berikut merupakan hasil dan pembahasan dari penelitian yang telah penulis lakukan:

\section{A. Hasil Game}

a. Tampilan Halaman Awal

Tampilan utama pada game edukasi fotosintesis ini berupa loading bar yang akan menuju ke halaman menu utama ditunjukkan pada Gambar 2.

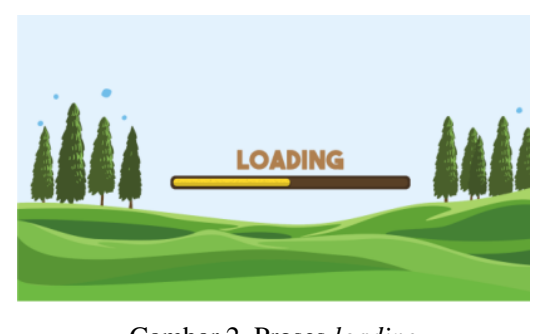

Gambar 2. Proses loading

b. Tampilan Menu Utama

Menu utama pada game Power Fotosintesis terdapat menu berupa tombol main, bantuan, informasi, pengaturan suara dan tombol keluar seperti pada Gambar 3.

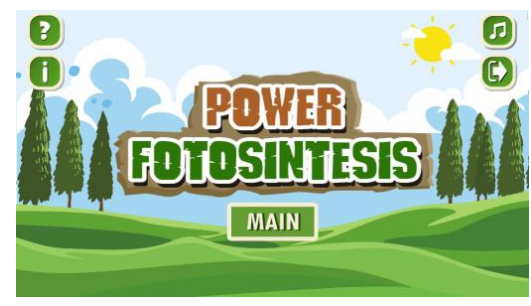

Gambar 3(a). Menu Utama 


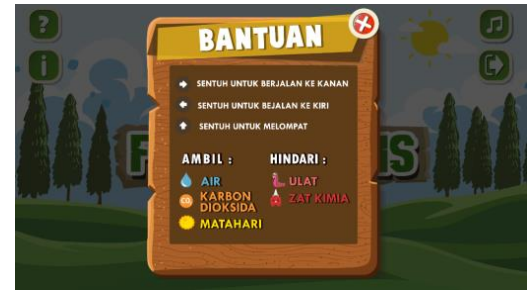

Gambar 3(b). Popup Bantuan

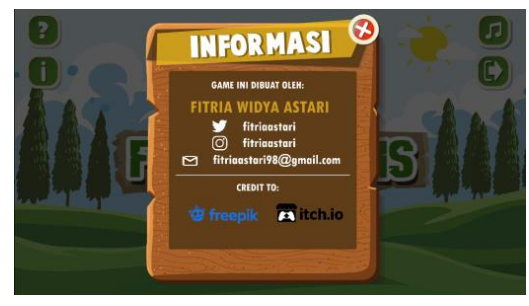

Gambar 3(c). Popup Informasi

Tampilan popup pada Gambar 3(b) berisi bantuan kepada pengguna cara untuk memainkan game Power Fotosintesis. Gambar 3(c) berisi informasi mengenai game. Tombol close akan mengghilangkan popup pada halaman menu utama.

c. Tampilan Intro

Tampilan intro terdapat materi fotosintesis yang berupa animasi pada Gambar 4.

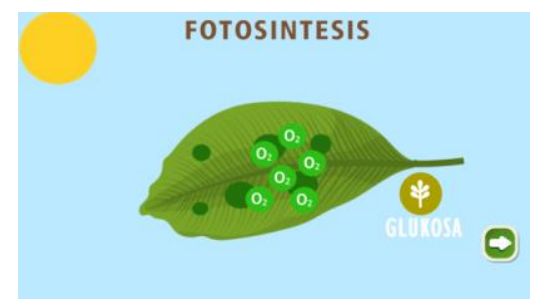

Gambar 4. Tampilan animasi materi fotosintesis

Intro game ini ditunjukkan pada Gambar 4 berupa penjelasan mengenai proses terjadinya fotosintesis dengan penggambaran komponen yang mengenai daun dan juga hasil dari fotosintesis.

\section{d. Tampilan Level 1}

Pemainan ini memiliki misi yang sama yaitu mengambil komponen untuk fotosintesis berupa air, karbondioksida dan matahari. Hanya saja dibedakan dengan jumlah komponen yang diambil. Semakin tinggi level maka komponen yang diambil akan lebih banyak. Tampilan level 1 ditunjukkan pada Gambar 5.

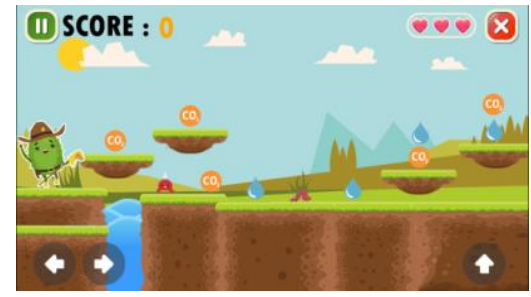

Gambar 5. Level 1

\section{e. Tampilan Lose dan Win}

Tampilan popup pada Gambar 6(a) muncul ketika player berhasil mengambil komponen seperti yang tertulis pada misi game. Sedangkan popup lose Gambar 6(b) akan muncul ketika nyawa player habis karena mengenai zat kimia dan ulat.

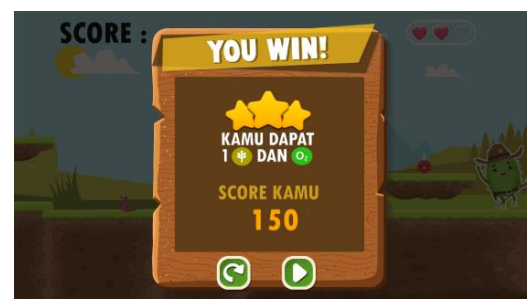

Gambar 6(a). Popup Win

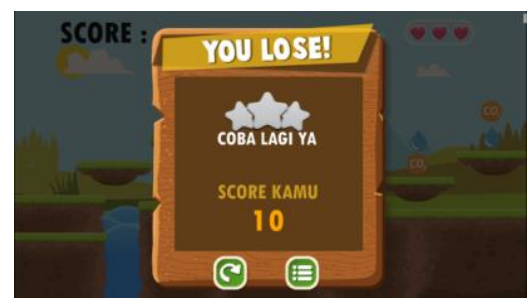

Gambar 6(b). Popup Lose

\section{B. Pengujian Blackbox}

Blackbox testing berfokus pada spesifikasi fungsional dari sebuah software, tester dapat mendefinisikan kumpulan kondisi input dan melakukan pengetesan pada spesifikasi fungsional program [14]. Pengujian menggunakan blackbox dilakukan dengan menggunakan dekstop dan juga smartphone.

Alur pengujian mulai dari membuka aplikasi game edukasi kemudian muncul loading bar yang menuju halaman utama. Halaman utama dilakukan penhujian apakah tombol sudah berfungsi sebagaimana mestinya. Mulai dari tombol pengaturan suara, tombol bantuan, tombol informasi dan tombol keluar dari game. Kemudian menekan tombol main yang membawa player menuju halaman intro. Halaman intro diharapkan penjelasan proses fotosintesis berupa animasi dan suara dapat berjalan sesuai. Menuju ke halaman level select, player hanya dapat memilih level yang tidak terkunci, maka player harus melewati level awal untuk menuju ke level berikutnya. Hasil uji blackbox pada game Power Fotosintesis 
dapat dimainkan tanpa kendala ditunjukkan pada Tabel 4 dan Tabel 5.

Tabel 4. Pengujian Blackbox Edugame Power Fotosintesis

\begin{tabular}{|c|c|c|c|}
\hline Kelas Uji & Skenario Uji & Hasil yang Diharapkan & $\begin{array}{c}\text { Keterang } \\
\text { an }\end{array}$ \\
\hline $\begin{array}{l}\text { Halaman } \\
\text { Awal }\end{array}$ & Loader & $\begin{array}{l}\text { Tampil loading bar dan } \\
\text { menuju menu utama }\end{array}$ & Diterima \\
\hline \multirow{6}{*}{$\begin{array}{l}\text { Menu } \\
\text { Utama }\end{array}$} & Tombol bantuan & Muncul popup cara bermain & Diterima \\
\hline & $\begin{array}{l}\text { Tombol close } \\
\text { pada popup }\end{array}$ & Popup bantuan menghilang & Diterima \\
\hline & $\begin{array}{l}\text { Tombol } \\
\text { informasi }\end{array}$ & $\begin{array}{l}\text { Muncul popup informasi } \\
\text { game }\end{array}$ & Diterima \\
\hline & $\begin{array}{l}\text { Tombol } \\
\text { pengaturan suara }\end{array}$ & $\begin{array}{l}\text { Suara dapat berbunyi dan } \\
\text { mati }\end{array}$ & Diterima \\
\hline & Tombol keluar & Muncul popup keluar game & Diterima \\
\hline & Tombol main & Menuju ke halaman intro & Diterima \\
\hline \multirow[t]{2}{*}{ Intro } & Memulai intro & $\begin{array}{l}\text { Suara berbunyi dan muncul } \\
\text { penjelasan dengan animasi }\end{array}$ & Diterima \\
\hline & Tombol next & $\begin{array}{l}\text { Menuju ke halaman level } \\
\text { select dan suara berhenti }\end{array}$ & Diterima \\
\hline \multirow[t]{2}{*}{$\begin{array}{l}\text { Level } \\
\text { Select }\end{array}$} & Pilih level & $\begin{array}{l}\text { Menuju ke halaman level } \\
\text { yang dipilih }\end{array}$ & Diterima \\
\hline & Tombol exit & Menuju ke menu utama & Diterima \\
\hline
\end{tabular}

Pada halaman level dikatakan berfungsi sesuai output yang diinginkan apabila misi yang diberikan telah dijalankan maka akan muncul popup win sedangkan apabila nyawa telah habis maka muncul popup lose.

Tabel 5. Pengujian Blackbox Edugame Power Fotosintesis

\begin{tabular}{|c|c|c|c|}
\hline Kelas Uji & Skenario Uji & Hasil yang Diharapkan & $\begin{array}{l}\text { Keterang } \\
\text { an }\end{array}$ \\
\hline \multirow{14}{*}{$\begin{array}{l}\text { Level } 1 \\
\text { dan Level } \\
2\end{array}$} & Memulai Level & $\begin{array}{l}\text { Play sound dan tampil misi } \\
\text { untuk player }\end{array}$ & Diterima \\
\hline & Tombol navigasi & $\begin{array}{l}\text { Player berjalan maju, } \\
\text { mundur dan lompat }\end{array}$ & Diterima \\
\hline & $\begin{array}{l}\text { Mengenai air, } \\
\text { karbondioksida } \\
\text { dan cahaya }\end{array}$ & $\begin{array}{l}\text { Play sound effect dan score } \\
\text { bertambah }\end{array}$ & Diterima \\
\hline & $\begin{array}{l}\text { Mengenai zat } \\
\text { kimia dan ulat }\end{array}$ & $\begin{array}{l}\text { Animasi flash dan nyawa } \\
\text { berkurang }\end{array}$ & Diterima \\
\hline & Tombol pause & Muncul popup pause & Diterima \\
\hline & $\begin{array}{l}\text { Tombol ok pada } \\
\text { popup pause }\end{array}$ & Lanjut ke permainan & Diterima \\
\hline & $\begin{array}{l}\text { Tombol close } \\
\text { pada popup } \\
\text { pause }\end{array}$ & Menuju halaman level select & Diterima \\
\hline & Tombol exit & Menuju halaman level select & Diterima \\
\hline & Nyawa habis & Muncul popup lose & Diterima \\
\hline & $\begin{array}{l}\text { Tombol restart } \\
\text { pada popup lose }\end{array}$ & $\begin{array}{l}\text { Tombol restart pada popup } \\
\text { lose }\end{array}$ & Diterima \\
\hline & $\begin{array}{l}\text { Tombol menu } \\
\text { pada popup lose }\end{array}$ & $\begin{array}{l}\text { Menuju ke halaman menu } \\
\text { utama }\end{array}$ & Diterima \\
\hline & $\begin{array}{l}\text { Menyelesaikan } \\
\text { Level }\end{array}$ & $\begin{array}{l}\text { Play sound dan muncul } \\
\text { popup win }\end{array}$ & Diterima \\
\hline & $\begin{array}{l}\text { Tombol restart } \\
\text { pada popup win }\end{array}$ & Mengulang level game & Diterima \\
\hline & $\begin{array}{l}\text { Tombol play } \\
\text { pada popup win }\end{array}$ & Menuju halaman level select & Diterima \\
\hline \multirow[t]{5}{*}{ Level 3} & Memulai Level & $\begin{array}{l}\text { Play sound dan tampil misi } \\
\text { untuk player }\end{array}$ & Diterima \\
\hline & Tombol navigasi & $\begin{array}{l}\text { Player berjalan maju, } \\
\text { mundur dan lompat }\end{array}$ & Diterima \\
\hline & $\begin{array}{l}\text { Mengenai air, } \\
\text { karbondioksida } \\
\text { dan cahaya }\end{array}$ & $\begin{array}{l}\text { Play sound effect dan score } \\
\text { bertambah }\end{array}$ & Diterima \\
\hline & $\begin{array}{l}\text { Mengenai zat } \\
\text { kimia dan ulat }\end{array}$ & $\begin{array}{l}\text { Animasi flash dan nyawa } \\
\text { berkurang }\end{array}$ & Diterima \\
\hline & Tombol pause & Muncul popup pause & Diterima \\
\hline
\end{tabular}

\begin{tabular}{|l|l|l|c|}
\hline \multirow{7}{*}{} & $\begin{array}{l}\text { Tombol } \text { ok pada } \\
\text { popup pause }\end{array}$ & Lanjut ke permainan & Diterima \\
\cline { 2 - 4 } & $\begin{array}{l}\text { Tombol } \text { close } \\
\text { pada popup } \\
\text { pause }\end{array}$ & Menuju halaman level select & Diterima \\
\cline { 2 - 4 } & Tombol exit & Menuju halaman level select & Diterima \\
\cline { 2 - 4 } Nyawa habis & Muncul popup lose & Diterima \\
\cline { 2 - 4 } & $\begin{array}{l}\text { Tombol restart } \\
\text { pada popup lose }\end{array}$ & $\begin{array}{l}\text { Tombol restart pada popup } \\
\text { lose }\end{array}$ & Diterima \\
\cline { 2 - 4 } & $\begin{array}{l}\text { Tombol menu } \\
\text { pada popup lose }\end{array}$ & $\begin{array}{l}\text { Menuju ke halaman menu } \\
\text { utama }\end{array}$ & Diterima \\
\cline { 2 - 4 } & $\begin{array}{l}\text { Menyelesaikan } \\
\text { Level }\end{array}$ & $\begin{array}{l}\text { Play sound dan muncul } \\
\text { popup win }\end{array}$ & Diterima \\
\cline { 2 - 4 } & $\begin{array}{l}\text { Tombol restart } \\
\text { pada popup win }\end{array}$ & Mengulang level game & Diterima \\
\cline { 2 - 4 } & $\begin{array}{l}\text { Tombol } \text { close } \\
\text { pada popup win }\end{array}$ & Menuju halaman level select & Diterima \\
\hline
\end{tabular}

\section{Pengujian System Usability Scale (SUS)}

Pengujian dengan metode System Usability Scale (SUS) terdiri dari 10 pernyataan kepada responden dengan jawaban mulai dari 1 (sangat tidak setuju) sampai 5 (sangat setuju) [15]. Hasil dari kuesioner kemudian dihitung untuk mengetahui nilai yang menggambarkan kualitas dari aplikasi menggunakan metode System Usability Scale (SUS). Pengujian ini melibatkan 30 siswa kelas 5 SD Negeri Pabelan 2.

SUS Score dihasilkan dari konversi hasil respon yang terdapat pada kuesioner dalam bentuk angka. Kemudian dilakukan perhitungan dimana respon pernyataan dengan nomor ganjil dikurangi 1 dan pernyataan dengan nomor genap hasil dari konversi respon digunakan untuk mengurangi angka 5. Sehingga diperoleh hasil dengan angka 0 sampai 4, dimana 4 adalah nilai paling tinggi. Selanjutnya nilai dari setiap pernyataan ditotal kemudian dikalikan dengan 2,5. Hasilnya, nilai yang diperoleh dari pengujian menggunakan metode System Usability Scale (SUS) memiliki rentang 0 sampai 100. Hasil dari pengujian menggunakan metode SUS ditunjukkan pada Tabel 6 .

Tabel 6. Hasil Kuesioner

\begin{tabular}{|r|r|r|r|r|r|r|r|r|r|r|r|r|}
\hline \multirow{2}{*}{ No } & \multicolumn{7}{|c|}{ Pernyataan } & Total & $\begin{array}{c}\text { SUS } \\
\text { Score } \\
\text { (Total } \\
\text { *2.5) }\end{array}$ \\
\hline & P1 & P2 & P3 & P4 & P5 & P6 & P7 & P8 & P9 & P10 & & \\
\hline 1 & 4 & 4 & 3 & 3 & 3 & 4 & 3 & 0 & 4 & 3 & 31 & 77.5 \\
\hline 2 & 2 & 1 & 2 & 1 & 3 & 3 & 4 & 1 & 4 & 0 & 21 & 52.5 \\
\hline 3 & 4 & 4 & 4 & 4 & 4 & 4 & 3 & 4 & 4 & 4 & 39 & 97.5 \\
\hline 4 & 3 & 3 & 3 & 3 & 3 & 3 & 3 & 3 & 3 & 3 & 30 & 75 \\
\hline 5 & 3 & 3 & 1 & 2 & 3 & 2 & 1 & 3 & 3 & 0 & 21 & 52.5 \\
\hline 6 & 3 & 3 & 3 & 3 & 3 & 3 & 2 & 3 & 1 & 2 & 26 & 65 \\
\hline 7 & 4 & 2 & 4 & 1 & 4 & 4 & 4 & 4 & 4 & 0 & 31 & 77.5 \\
\hline 8 & 4 & 3 & 3 & 1 & 4 & 3 & 2 & 1 & 3 & 0 & 24 & 60 \\
\hline 9 & 1 & 1 & 4 & 0 & 2 & 1 & 4 & 3 & 2 & 0 & 18 & 45 \\
\hline 10 & 3 & 3 & 3 & 4 & 3 & 3 & 1 & 3 & 3 & 0 & 26 & 65 \\
\hline 11 & 4 & 3 & 3 & 1 & 4 & 3 & 3 & 3 & 4 & 1 & 29 & 72.5 \\
\hline 12 & 1 & 4 & 3 & 3 & 3 & 3 & 3 & 3 & 3 & 0 & 26 & 65 \\
\hline 13 & 3 & 3 & 3 & 4 & 3 & 3 & 3 & 4 & 3 & 0 & 29 & 72.5 \\
\hline 14 & 3 & 4 & 4 & 3 & 4 & 2 & 1 & 4 & 4 & 1 & 30 & 75 \\
\hline 15 & 4 & 4 & 3 & 2 & 4 & 4 & 2 & 4 & 3 & 4 & 34 & 85 \\
\hline 16 & 4 & 4 & 4 & 1 & 4 & 4 & 3 & 4 & 4 & 3 & 31 & 87.5 \\
\hline 17 & 4 & 4 & 4 & 1 & 4 & 4 & 3 & 4 & 4 & 3 & 31 & 87.5 \\
\hline 18 & 4 & 3 & 3 & 3 & 3 & 3 & 4 & 3 & 4 & 2 & 32 & 80 \\
\hline
\end{tabular}




\begin{tabular}{|r|r|r|r|r|r|r|r|r|r|r|r|r|}
\hline 19 & 4 & 3 & 3 & 3 & 4 & 3 & 4 & 2 & 4 & 2 & 32 & 80 \\
\hline 20 & 4 & 2 & 3 & 3 & 1 & 4 & 4 & 4 & 3 & 2 & 30 & 75 \\
\hline 21 & 4 & 3 & 3 & 1 & 4 & 3 & 4 & 3 & 4 & 3 & 32 & 80 \\
\hline 22 & 4 & 4 & 4 & 3 & 4 & 4 & 1 & 4 & 4 & 4 & 36 & 90 \\
\hline 23 & 3 & 3 & 4 & 1 & 1 & 3 & 3 & 4 & 1 & 1 & 24 & 60 \\
\hline 24 & 4 & 3 & 3 & 1 & 1 & 3 & 3 & 3 & 3 & 3 & 27 & 67.5 \\
\hline 25 & 3 & 3 & 3 & 1 & 4 & 3 & 3 & 3 & 3 & 1 & 27 & 67.5 \\
\hline 26 & 3 & 3 & 3 & 1 & 3 & 3 & 3 & 3 & 3 & 3 & 28 & 70 \\
\hline 27 & 4 & 4 & 3 & 1 & 1 & 1 & 4 & 3 & 3 & 0 & 24 & 60 \\
\hline 28 & 3 & 3 & 3 & 1 & 3 & 3 & 1 & 3 & 2 & 1 & 23 & 57.5 \\
\hline 29 & 3 & 3 & 4 & 3 & 4 & 3 & 4 & 4 & 4 & 3 & 35 & 87.5 \\
\hline 30 & 3 & 3 & 3 & 3 & 3 & 3 & 3 & 3 & 3 & 0 & 27 & 67.5 \\
\hline \multicolumn{10}{|c|}{} \\
\hline
\end{tabular}

Keterangan Kode Pernyataan:

P1: Menurut saya, saya menyukai game ini sehingga akan memainkannya berkali-kali

P2: Menurut saya game ini terlalu rumit dimainkan

P3: Menurut saya game ini mudah digunakan

P4: Saya membutuhkan bantuan orang lain untuk memainkan game ini (tidak dapat bermain sendiri tanpa dibantu)

P5: Saya menganggap bagian-bagian game ini dapat dimainkan dengan baik

P6: Menurut saya cara bermain game ini membingungkan

P7: Menurut saya orang lain akan belajar bermain game ini dengan sangat cepat (mudah)

P8: Saya menganggap game ini tidak praktis (sulit) dimainkan

P9: Saya merasa bisa memainkan game ini

P10: Saya perlu belajar banyak untuk memainkan game ini

Hasil kuesioner dihitung menggunakan persamaan 1.

Menghitung nilai rata-rata $=\sum \quad \underline{i} \ldots \ldots . .(1)$

Dimana $x_{i}$ : nilai score responden

$$
N \text { : jumlah responden }
$$

Maka diperoleh nilai rata-rata $=-=71,83$

Hasil perhitungan diperoleh nilai rata-rata sebesar 71,83. Nilai 71,83 menunjukkan bahwa aplikasi yang dibuat memiliki kualitas baik dan dapat dimanfaatkan oleh pengguna. Game edukasi fotosintesis dapat diterapkan dalam menunjang penyampaian materi pada siswa. Berdasarkan penghitungan hasil SUS Score diperoleh hasil bahwa 7 siswa berada pada rentang 41-60, 17 siswa pada rentang score 61-80 dan 6 siswa berada pada rentang 81-100. Hasil tersebut dapat diasumsikan bahwa siswa dapat menerima game edukasi fotosintesis. Berikut ini merupakan hasil rekapitulasi dari SUS Score yang divisualisasikan dalam bentuk grafik pada Gambar 7 .

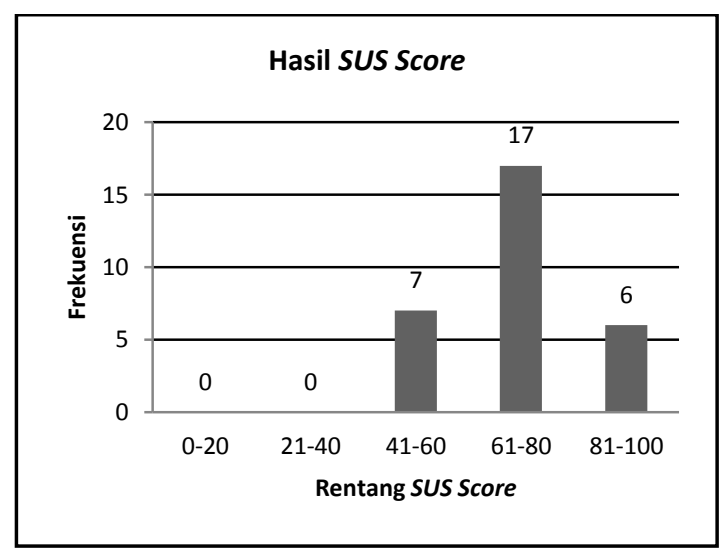

Gambar 7. Grafik Sebaran SUS Score

\section{PENUTUP}

Game edukasi Power Fotosintesis dapat digunakan sebagai media pembelajaran dalam menunjang penyampaian materi fotosintesis dengan cara yang menyenangkan pada siswa berbasis android. Berdasarkan pengujian blackbox yang telah dilakukan didapatkan hasil bahwa game edukasi ini dapat berjalan tanpa ada kendala dalam pengujian menggunakan dekstop maupun smartphone.

Secara keseluruhan score yang diperoleh dalam pengujian menggunakan metode System Usability Scale (SUS) adalah 71,83. Menunjukkan bahwa game edukasi Power Fotosintesis mempunyai kualitas yang baik dan dapat diterima ataupun dimanfaatkan oleh pengguna.

\section{DAFTAR PUSTAKA}

[1] Haryanto, "Sains untuk SD/MI kelas V". Jakarta: Erlangga, 2006. pp.52.

[2] W. A. Sanjaya, "Aplikasi Pembelajaran Fotosintesis Untuk Kelas Lima Sekolah Dasar Ar-Rafi Berbasis Flash Flash-Based Learning Photosynthesis for Grade Ar-Rafi Elementary School," e-Proceeding Appl. Sci., vol. 2, no. 3, pp. 867-872, 2016.

[3] K. W. Sari, S. Saputro, and B. Hastuti, "Pengembangan Game Edukasi Kimia Berbasis Role Playing Game (RPG) pada Materi Struktur Atom sebagai Media Pembelajaran Mandiri untuk Siswa Kelas X SMA di Kabupaten Purworejo," J. Pendidik. Kim., vol. 3, no. 2, pp. 96-104, 2014.

[4] D. Gentile, "Pathological Video-Game Use Among Youth Ages 8 to 18," Psychol. Sci., vol. 20, no. 5, pp. 594-602, 2009.

[5] E. Handriyantini, "Permainan Edukatif ( Educational Games ) Berbasis Komputer untuk Siswa Permainan Edukatif ( Educational Games ) Berbasis Komputer untuk Siswa Sekolah Dasar," e-Indonesia Initiat. 2009, no. June 2009, pp. 130-135, 2015.

[6] W. I. Nurhayati, “Improving Studets' Interest Through Games Method In Learning Social Science Education," Int. J. Pedagog. Soc. Stud., vol. 2, no. 1, p. 64, 2018.

[7] M. R. Rahadi, K. I. Satoto, and I. P. Windasari, "Perancangan Game Math Adventure Sebagai Media Pembelajaran Matematika Berbasis Android," J. Teknol. dan Sist. Komput., vol. 4, no. 1, p. 44, 2017.

[8] Edward, S. L. Learning Process and Violent Video Games. Hand Book of Research on Effective Electronic Game in Education. Florida: University of Florida, 2009. 
[9] W. E. Mueller and G. H. Massiha, "A Interactive Game to Enhance Student Understanding of Materials Management," Int. J. Eval. Res. Educ., vol. 1, no. 2, pp. 45-50, 2013.

[10] A. V. Vitianingsih, "Game Edukasi Berbasis Android Sebagai Media Pembelajaran Untuk Anak Usia Dini,” J. Inf., vol. 1, no. 1, pp. 46-58, 2016.

[11] D. I. Nurrahim and E. Sudarmilah, "EduGame Sejarah Islam Masuk Indonesia," J. IlmiahTeknik Elektro, vol. 03, no. 2, 2016.

[12] E. Sudarmilah, R. Ferdiana, L. E. Nugroho, A. Susanto, and N. Ramdhani, "Tech review: Game platform for upgrading counting ability on preschool children," Proc. - 2013 Int. Conf. Inf. Technol. Electr. Eng.
"Intelligent Green Technol. Sustain. Dev. ICITEE 2013, pp. 226-231, 2013.

[13] I. Summerville, "Software Engineering (Rekayasa Perangkat Lunak)". Jakarta: Erlangga, 2011.

[14] M. S. Mustaqbal, R. F. Firdaus, and H. Rahmadi, "Pengujian Aplikasi Menggunakan Black Box Testing Boundary Value Analysis," Penguji. Apl. Menggunakan Black Box Test. Bound. Value Anal. (Studi Kasus Apl. Prediksi Kelulusan SNMPTN), vol. I, no. 3, p. 34, 2015.

[15] J. Sauro. "SUStified? Little Known System Usability Scale Facts", http://uxpmagazine.org/sustified, 2011. 